\title{
Nanoparticles of barium induce apoptosis in human phagocytes
}

\author{
This article was published in the following Dove Press journal: \\ International Journal of Nanomedicine \\ 28 September 2015 \\ Number of times this article has been viewed
}

\section{Luana Mores \\ Eduardo Luzia França \\ Núbia Andrade Silva \\ Eliane Aparecida Suchara \\ Adenilda Cristina Honorio- \\ França}

Institute of Biological and Health Science, Federal University of Mato

Grosso, Barra do Garças, Mato

Grosso, Brazil
Correspondence: Adenilda Cristina Honorio-França

Instituto de Ciências Biológicas e da

Saúde, Universidade Federal de Mato

Grosso, Rodovia BR070, Km 5 s/number,

Barra do Garças, Mato Grosso, CEP

78698-000, Brazil

Tel +55 6634055317

Fax +55 663402 III 7

Email denifran@terra.com.br
Purpose: Nutrients and immunological factors of breast milk are essential for newborn growth and the development of their immune system, but this secretion can contain organic and inorganic toxins such as barium. Colostrum contamination with barium is an important issue to investigate because this naturally occurring element is also associated with human activity and industrial pollution. The study evaluated the administration of barium nanoparticles to colostrum, assessing the viability and functional activity of colostral mononuclear phagocytes.

Methods: Colostrum was collected from 24 clinically healthy women (aged 18-35 years). Cell viability, superoxide release, intracellular $\mathrm{Ca}^{2+}$ release, and phagocyte apoptosis were analyzed in the samples.

Results: Treatment with barium lowered mononuclear phagocyte viability, increased superoxide release, and reduced intracellular calcium release. In addition, barium increased cell death by apoptosis.

Conclusion: These data suggest that nanoparticles of barium in colostrum are toxic to cells, showing the importance of avoiding exposure to this element.

Keywords: barium chloride, colostrum, immune cells, intracellular $\mathrm{Ca}^{2+}$, immunotoxicology

\section{Introduction}

Breast milk contains several immunological components, including macrophages, neutrophils, lymphocytes, cytokines, immunoglobulins, complement proteins, chemokines, growth factors, and proteins, that can affect child's immune maturation. ${ }^{1-5}$ Both neutrophils and macrophages play a key role in host defense against microorganisms, ${ }^{6}$ killing bacteria, fungi, and protozoa by phagocytosis. ${ }^{7-11}$ However, in addition to beneficial cellular components, breast milk can contain environmental pollutants such as organic or inorganic substances ${ }^{12}$ that are transferred from the mother to the baby. ${ }^{13}$ Thus, interest in the biological effects of exposure to toxic metals has increased, with biological fluids such as blood, urine, and breast milk analyzed by biomonitoring. ${ }^{13-15}$

Metals are the most important category of natural elements that can be extracted from the environment to be used in industrial processes. They can spread in the environment and accumulate in body tissues, possibly causing toxic effects even in small amounts. ${ }^{16}$ Some studies report the effects of human exposure to barium (Ba) and other metals. ${ }^{13,17-23}$ Exposure to barium deserves particular attention because this element is commonly found in drinking water ${ }^{24}$ and can be released into the environment by natural disaggregation of rocks and minerals ${ }^{25}$ or as polluting waste from industry and human activities. ${ }^{25,26}$

The toxicity of compounds containing barium depends on their solubility, ${ }^{25}$ that is, soluble salts are more toxic than insoluble salts. ${ }^{27}$ The action mechanism of barium appears 
to involve the blocking of $\mathrm{K}^{+}$and $\mathrm{NaK}^{+}$channels in the cell membrane and increasing potassium transfer from an extracellular to intracellular medium. ${ }^{25,28}$ The main effect of barium is the stimulation of all types of muscles, ${ }^{28,29}$ and the dominant clinical condition of barium poisoning in humans seems to be hypocalcemia, which paralyzes skeletal muscles. ${ }^{28}$

Although barium is found at low levels in the environment, the health consequences of long-term exposure have yet to be fully explained. ${ }^{30}$ Considering that barium can contaminate breast milk, thereby affecting components of the still-developing baby's immune system, the aim of this study was to evaluate the effects of barium nanoparticles on the viability and functional activity of mononuclear (MN) cells of colostrum.

\section{Materials and methods Subjects}

Approximately $15 \mathrm{~mL}$ of colostrum was collected at the Health System Program of Barra do Garças, Mato Grosso, Brazil, from clinically healthy women ( $18-35$ years old; $N=24)$ who had no diagnosed diseases, such as hypertension and diabetes, and who reported not consuming alcoholic beverages or tobacco. All the mothers had given birth to healthy term babies through surgical delivery. This study was approved by the institutional Research Ethics Committee of the Federal University of Mato Grosso (protocol number: 354/CEPHUJM/07), and all the mothers signed informed consent.

\section{Colostrum sampling and separation of colostral cells}

Colostrum was collected in sterile plastic tubes between 48 hours and 72 hours postpartum. The samples were centrifuged $\left(160 \times g, 4^{\circ} \mathrm{C}\right)$ for 10 minutes. The upper fat layer was discarded, and the aqueous supernatant was stored at $-80^{\circ} \mathrm{C}$ for later analyses. Cells were separated by a Ficoll-Paque gradient (Pharmacia, Upsala, Sweden), producing preparations with $98 \%$ of pure $\mathrm{MN}$ cells at concentration with the average of $4.2 \pm 0.7$, analyzed by light microscopy. Purified MN cells were resuspended independently in serum-free 199 medium at a final concentration of $2 \times 10^{6}$ cells $/ \mathrm{mL}$. The cells were used for assays of viability, superoxide release, calcium release, and apoptosis.

\section{Treatment of MN colostral phagocytes with barium chloride}

To assess the effect of barium chloride on cellular viability, MN phagocytes $\left(2 \times 10^{6}\right.$ cells $\left./ \mathrm{mL}\right)$ were incubated with $10 \mu \mathrm{L}$ of barium chloride (Sigma-Aldrich Co., St Louis, MO, USA) at the concentrations of $1 \mathrm{~g} / \mathrm{L}, 1 \mu \mathrm{g} / \mathrm{L}, 10 \mathrm{ng} / \mathrm{L}$, and $1 \mathrm{ng} / \mathrm{L}$ for $0,30,60,90,120$, and 180 minutes at $37^{\circ} \mathrm{C}$.

To investigate the effect of barium chloride on superoxide anion release, intracellular $\mathrm{Ca}^{2+}$ release, and apoptosis, $\mathrm{MN}$ phagocytes $\left(2 \times 10^{6}\right.$ cells $\left./ \mathrm{mL}\right)$ were incubated with $10 \mu \mathrm{L}$ of barium chloride at concentration $1 \mathrm{ng} / \mathrm{L}$ for 60 minutes at $37^{\circ} \mathrm{C}$. The phagocytes were then washed twice with 199 medium at $4^{\circ} \mathrm{C}$ and immediately used in the assays. A control was performed without barium chloride.

To analyze the effects of intracellular $\mathrm{Ca}^{2+}$ on barium chloride action, colostral MN phagocytes $\left(2 \times 10^{6}\right.$ cells $\left./ \mathrm{mL}\right)$ were incubated with $10 \mu \mathrm{L}$ of 8-(diethylamino)octyl-3,4,5trimethylbenzoate hydrochloride (TMB-8; Sigma-Aldrich Co.) at a final concentration of $0.1 \mathrm{mM}$ for 60 minutes at $37^{\circ} \mathrm{C}$, as an intracellular calcium antagonist during 60 minutes at $37^{\circ} \mathrm{C} .^{31}$ The $\mathrm{MN}$ phagocytes were then washed two times with 199 medium at $4^{\circ} \mathrm{C}$ and immediately used in the assays.

\section{Viability assay}

Cellular viability was evaluated by the acridine orange method. ${ }^{9}$ The cells were pretreated or not with barium chloride as previously described. Cells were resuspended in serum-free 199 medium and centrifuged. The supernatant was discarded, and the sediment dyed with $200 \mu \mathrm{g} / \mathrm{L}$ of acridine orange (Sigma-Aldrich Co.), $14.4 \mathrm{~g} / \mathrm{L}$ for 1 minute. The sediment was resuspended in cold 199 medium, washed twice, and observed under immunofluorescence microscope at $400 \times$ and $1,000 \times$ magnifications.

We stained the slides with acridine orange and counted 100 cells. The viability index was calculated as the ratio between orange-stained (dead) and green-stained (alive) cells $\times 100{ }^{9}$ All the experiments were performed in duplicate.

\section{Release of superoxide anion}

Superoxide release was determined by cytochrome C (SigmaAldrich Co.) reduction. ${ }^{7}$ Briefly, $\mathrm{MN}$ colostrum phagocytes treated with barium chloride were resuspended in phosphatebuffered saline (PBS), pH 7.4 containing $2.6 \mathrm{mM} \mathrm{CaCl}_{2}$, $2 \mathrm{mM} \mathrm{MgCl}_{2}$, and $2 \mathrm{mg} / \mathrm{mL}$ cytochrome $\mathrm{C}$. The suspensions $(100 \mu \mathrm{L})$ were incubated for 60 minutes at $37^{\circ} \mathrm{C}$ on culture plates. The reaction rates were measured by absorbance at $550 \mathrm{~nm}$, and the results were expressed as nmol/ $\mathrm{O}_{2}^{-}$. All the experiments were performed in duplicate.

Intracellular $\mathrm{Ca}^{2+}$ release determined by fluorescence and flow cytometry

We performed fluorescence staining on the FACSCalibur (BD Biosciences, San Jose, CA, USA) to assess 
intracellular $\mathrm{Ca}^{2+}$ release in phagocytes. ${ }^{32}$ Cells were loaded with the fluorescent radiometric calcium indicator Fluo3-Acetoxymethyl (Fluo3-AM; Sigma-Aldrich Co.). Cell suspensions were pretreated or not with $50 \mu \mathrm{L}$ of barium chloride as previously described. A control was performed using cell suspensions, pretreated with TMB-8. Suspensions were centrifuged twice $(160 \times g, 10$ minutes, $4^{\circ} \mathrm{C}$ ) and resuspended in PBS-containing bovine serum albumin (BSA, $5 \mathrm{mg} / \mathrm{mL}$ ). Suspensions were centrifuged twice $\left(160 \times \mathrm{g}, 10\right.$ minutes, $\left.4^{\circ} \mathrm{C}\right)$ and resuspended in PBS-containing BSA $(5 \mathrm{mg} / \mathrm{mL})$. This suspension was incubated with $5 \mu \mathrm{L}$ of Fluo-3 $(1 \mu \mathrm{g} / \mathrm{mL})$ for 60 minutes at $37^{\circ} \mathrm{C}$. After incubation, cells were washed twice in PBScontaining BSA $\left(5 \mathrm{mg} / \mathrm{mL} ; 160 \times g, 10\right.$ minutes, $\left.4^{\circ} \mathrm{C}\right)$ and then analyzed by flow cytometry (FACSCalibur system; BD Biosciences). Fluo-3 was detected at 530/30 nm filter for intracellular $\mathrm{Ca}^{2+}$. The rate of intracellular $\mathrm{Ca}^{2+}$ release was expressed in geometric mean fluorescence intensity of Fluo-3. Data shown in the figures correspond to one of the several trials performed.

\section{Apoptosis assay}

The apoptosis assay was determined by Annexin V-FITC Apoptosis Detection Kit (Alexis ${ }^{\mathrm{TM}}$, San Diego, USA) according to the manufacturer's instructions. Untreated cells were used as negative controls, and cells treated with staurosporine (Sigma-Aldrich Co.), an inducer of apoptosis, were used as positive controls. ${ }^{33}$ The cells were resuspended in $500 \mu \mathrm{L}$ of binding buffer containing $5 \mu \mathrm{L}$ of Annexin V-FITC and $5 \mu \mathrm{L}$ of propidium iodide (PI) and then incubated for 10 minutes at room temperature. The fluorescence of the cells was analyzed by flow cytometry (FACSCalibur system; BD Biosciences). The obtained data were analyzed using CellQuest software. The cells were classified as follows: viable cells (annexin $\left.{ }^{-} / \mathrm{PI}^{-}\right)$, early apoptotic cells (annexin ${ }^{+} /$ $\left.\mathrm{PI}^{-}\right)$, late apoptotic cells $\left(\right.$annexin $\left.{ }^{+} / \mathrm{PI}^{+}\right)$, and necrotic cells $\left(\right.$ annexin $\left.{ }^{-} / \mathrm{PI}^{+}\right)$.

\section{Statistical analysis}

Data were expressed as the mean \pm standard deviation (SD). Analysis of variance with calculation of $F$ statistic and Tukey's multiple comparison test was used to evaluate the superoxide release anion, intracellular $\mathrm{Ca}^{2+}$ release, and apoptosis in the presence or absence of barium chloride. Statistical significance was considered when the $P$-value was $<0.05$.

\section{Results}

The women under study had an average $( \pm \mathrm{SD})$ age of $25.6 \pm 6.1$ years and gestational age of $38.6 \pm 1.3$ weeks. Mean $( \pm \mathrm{SD})$ newborn birth weight was $3,330 \pm 40 \mathrm{~g}$.

Regardless of exposure time, the viability index was lower in cells incubated with barium chloride. The lowest viability index was observed in cells incubated with $1 \mathrm{ng} / \mathrm{mL}$ of barium chloride for 60 minutes (Table 1).

MN phagocytes treated with barium chloride exhibited higher superoxide release than spontaneous release (Figure 1) and lower intracellular calcium. Treating colostrum phagocytes with TMB- 8 also reduced intracellular $\mathrm{Ca}^{2+}$ release by colostrum phagocytes, which was similar to that of cells treated with barium chloride (Table 2).

The annexin $\mathrm{V}$ assay detected barium-induced apoptosis of colostral MN phagocytes (Figure 2). In the treatment without barium chloride, MN phagocytes showed a lower apoptosis rate. The highest apoptosis index was observed in colostral $\mathrm{MN}$ phagocytes treated with barium chloride (Table 3 and Figure 3).

\section{Discussion}

The present study showed that nanoparticles of barium chloride are toxic for colostral MN phagocytes, reducing cell viability and intracellular calcium release and increasing apoptosis rate.

Barium toxicity is likely caused by $\mathrm{K}^{+}$channel blockade, changing cell membrane permeability to potassium. ${ }^{19,25,34}$

Table I Cellular viability index (\%) of colostrum mononuclear (MN) phagocytes (mean $\pm S D, N=6$ in each treatment)

\begin{tabular}{|c|c|c|c|c|c|}
\hline \multirow[t]{2}{*}{ MN phagocytes } & \multicolumn{5}{|c|}{ Incubation time (min) } \\
\hline & 0 & 30 & 60 & 120 & 180 \\
\hline $0 \mathrm{~g} / \mathrm{L} \mathrm{BaCl}_{2}$ & $94.8 \pm 2.6$ & $93.6 \pm 1.7$ & $91.4 \pm 1.3$ & $91.4 \pm 2.4$ & $86.4 \pm 0.9 *$ \\
\hline $\mathrm{I} g / \mathrm{L} \mathrm{BaCl}_{2}$ & $72.0 \pm 8.4^{a}$ & $70.4 \pm 3.9^{\mathrm{a}}$ & $68.4 \pm 15.2^{\mathrm{a}}$ & $71.2 \pm 5.8^{\mathrm{a}}$ & $62.4 \pm 4.7^{\mathrm{a}}$ \\
\hline I $\mu \mathrm{g} / \mathrm{L} \mathrm{BaCl} 2$ & $78.2 \pm 9.8^{\mathrm{a}}$ & $72.0 \pm 13.3^{\mathrm{a}}$ & $65.0 \pm 15.2^{\mathrm{a}}$ & $75.2 \pm 4.4^{a}$ & $62.4 \pm 7 . I^{\mathrm{a}}$ \\
\hline $10 \mathrm{ng} / \mathrm{L} \mathrm{BaCl}_{2}$ & $77.8 \pm 7.6^{a}$ & $71.6 \pm 11.0^{\mathrm{a}}$ & $67.4 \pm 12.9^{\mathrm{a}}$ & $72.8 \pm 5.3^{\mathrm{a}}$ & $69.4 \pm 5.6^{\mathrm{a}}$ \\
\hline I ng/L BaCl 2 & $75.2 \pm 5.4^{\mathrm{a}}$ & $73.0 \pm 5.7^{\mathrm{a}}$ & $59.4 \pm 8.7^{\mathrm{a}}$ & $72.8 \pm 5.4^{a}$ & $64.6 \pm 3.2^{\mathrm{a}}$ \\
\hline
\end{tabular}

Notes: $F$ (concentration) $=31.8720 ; P<0.000 \mathrm{I} . F$ (time) $=10.9795 ; P<0.000 \mathrm{I}$; adifferences between phagocytes treated (barium chloride $[\mathrm{BaCl}]$ ) and the control (without barium chloride), considering the same time of incubation; $* P<0.005$ indicates differences between the time of incubation, considering the same treatment. Abbreviations: SD, standard deviation; min, minutes. 


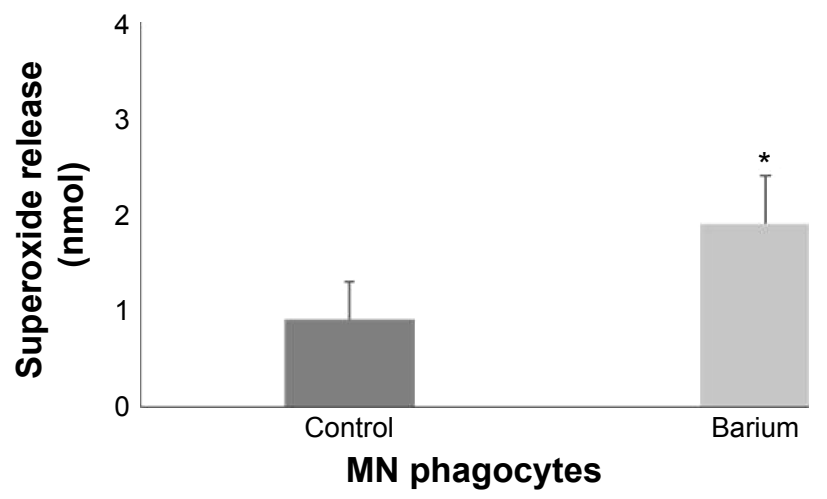

Figure I Superoxide release by blood mononuclear phagocytes (mean $\pm S D, N=6$ in each treatment).

Notes: Colostral mononuclear cells were treated or not with barium. $F=\mid 4.8023$, $P<0.0001$. *Differences between phagocytes treated with or without barium. Abbreviations: $\mathrm{MN}$, mononuclear; $\mathrm{SD}$, standard deviation.

It may also interact with calcium. ${ }^{35}$ The increase in superoxide levels modifies intracellular calcium release and phosphorylation during oxidative metabolism. ${ }^{6}$ In the present study, barium chloride exposure increased superoxide release and reduced calcium release by $\mathrm{MN}$ phagocytes. The formation of superoxide anion $\left(\mathrm{O}_{2}^{-}\right)$is a physiological mechanism for microorganism elimination. ${ }^{11,36}$ However, during oxidative stress, cells can produce a large amount of superoxide radicals. ${ }^{9,10}$

Intracellular calcium release promotes cellular activation $^{31,32,37}$ through self-regulation system. ${ }^{38}$ Even minor changes in plasma membrane alter $\mathrm{Ca}^{2+}$ permeability, triggering physiological responses and significant changes in the cytosolic concentration of this element. ${ }^{39}$

Monitoring intracellular calcium has become a useful tool in assessing cell activity. ${ }^{40}$ Interestingly, barium chloride also inhibited intracellular $\mathrm{Ca}^{2+}$ release in colostral MN phagocytes. In addition, we detected a synergistic effect of barium chloride plus TMB-8, since either combined or separately, they similarly inhibit intracellular $\mathrm{Ca}^{2+}$ release.

Table 2 Release of intracellular $\mathrm{Ca}^{2+}$ by colostral MN phagocytes exposed to barium

\begin{tabular}{lll}
\hline MN phagocytes & TMB-8 & Intracellular calcium release \\
\hline Control & No & $17.9 \pm 2.8$ \\
Control & Yes & $5.1 \pm 0.5^{\mathrm{a}}$ \\
$\mathrm{BaCl}_{2}$ & No & $5.1 \pm 0.5^{\mathrm{b}}$ \\
$\mathrm{BaCl}_{2}$ & Yes & $5.4 \pm 0.6^{\mathrm{b}}$ \\
\hline
\end{tabular}

Notes: Phagocytes were pretreated or not with 8-(diethylamino)octyl-3,4, 5-trimethoxybenzoate hydrochloride (TMB-8), incubated with barium chloride and loaded with fluorescent radiometric calcium indicator Fluo3-Acetoxymethyl (Fluo3AM). Results are expressed as mean $\pm S D$ ( $N=6$ per treatment). $F=44.9605 ; P<0.05$. a Differences between phagocytes treated with or without barium; bdifferences between TMB-8 use within each treatment.

Abbreviations: $\mathrm{MN}$, mononuclear; SD, standard deviation.

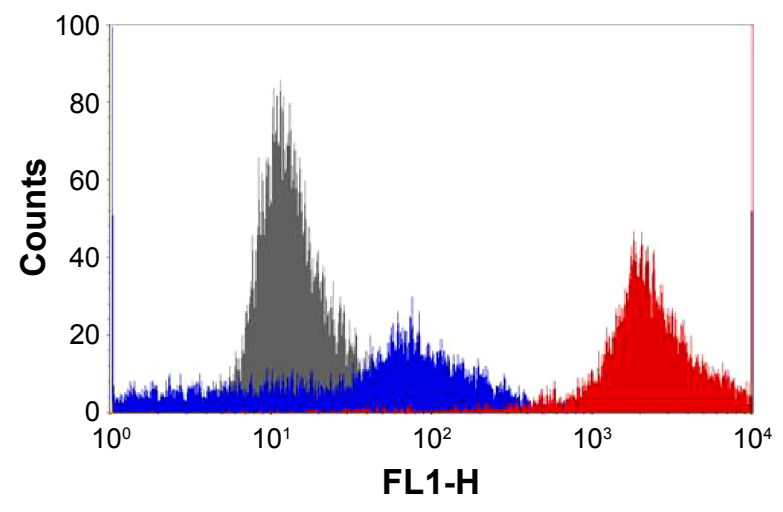

Cells $=$ Cells + staurosporine - Cells + barium

Figure 2 Apoptosis of colostral MN phagocytes exposed to barium (I ng/nL) and staurosporine (Sigma-Aldrich Co., St Louis, MO, USA) indicated by fluorescence intensity.

Notes: Cells were stained with Annexin V-FITC (Sigma-Aldrich Co.). Immunofluorescence analyses were carried out by flow cytometry (FACScalibur; BD Biosciences, San Jose, CA, USA).

The precise mechanisms regarding the action of barium on intracellular calcium homeostasis have yet to be elucidated, and studies of barium action on human cells are scarce. Other toxic metals ${ }^{41-44}$ have been found to trigger different responses in order to maintain intracellular calcium homeostasis, enhancing or suppressing intracellular calcium mobilization, eventually causing apoptosis. ${ }^{44}$

Trace elements play an important role in regulating cell growth and metabolism, including the control of apoptosis. ${ }^{45}$ In the present study, barium chloride exposure induced apoptosis in colostral MN phagocytes. Other studies describe the mechanisms involved in the death of other cell types due to barium chloride exposure. ${ }^{46}$ Other toxic metals were found to induce apoptosis and/or necrosis due to changes in intracellular calcium homeostasis and promotion of microvascular endothelial dysfunction. ${ }^{41,44,47}$ Our findings indicate that the barium chloride induced higher apoptosis rate but lower number of necrotic cells.

Here, the results suggest that trace amounts of barium chloride can change the function of colostral phagocytes and induce apoptosis. However, other investigations that

Table 3 Apoptosis (\%) and necrosis (\%) of colostral MN phagocytes exposed to barium chloride $(\mathrm{I} \mathrm{ng} / \mathrm{mL})$

\begin{tabular}{llll}
\hline & Viables Q1 & Apoptosis (Q2 + Q3) & Necrosis Q4 \\
\hline Control & $95.9 \pm 2.75$ & $3.9 \pm 1.85$ & $0.07 \pm 0.05$ \\
Barium chloride & $0.6 \pm 0.06^{*}$ & $99.4 \pm 2.5^{*}$ & $0.02 \pm 0.01 *$ \\
\hline
\end{tabular}

Notes: Results are expressed as mean and SD for six experiments. QI: viable cells (annexin-/PI-); Q2 (annexin $\left./ \mathrm{Pl}^{-}\right)$and Q3 (annexin $\left.{ }^{+} / \mathrm{Pl}^{+}\right)$: total apoptotic cells; and Q4: necrotic cells (annexin $/ / \mathrm{Pl}^{+}$). $* P<0.05$ (comparing cells treated with and without barium).

Abbreviations: MN, mononuclear; SD, standard deviation. 


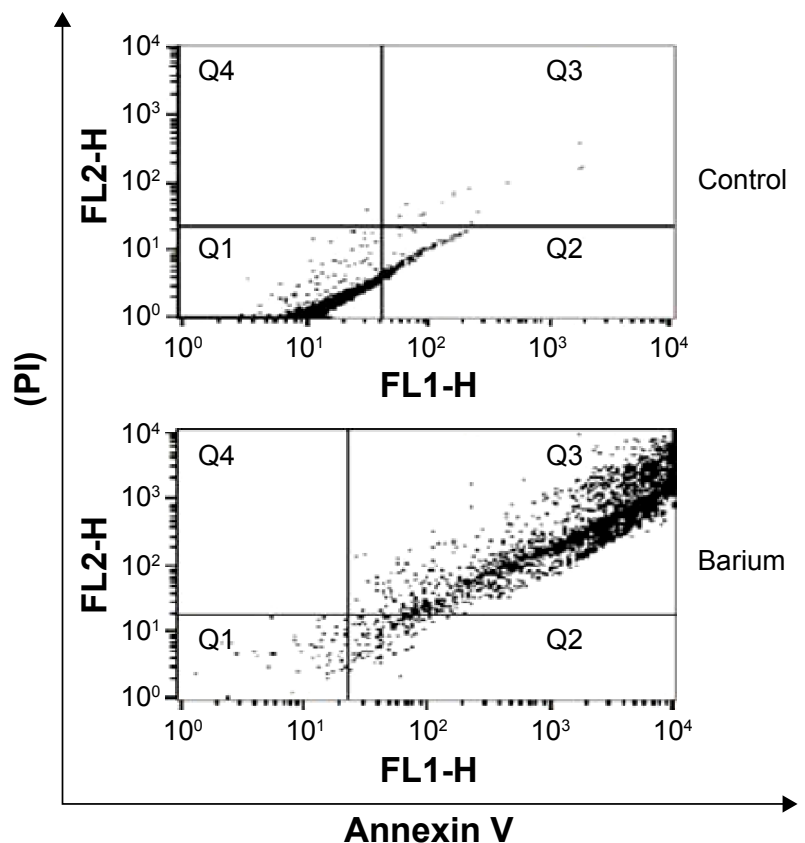

Figure 3 Barium chloride induces apoptosis in colostral MN phagocytes. Notes: Different types of cell death were assessed using flow cytometry with annexin $\mathrm{V} P \mathrm{Pl}$ staining. The sum of the upper-right (Q3) and lower-right (Q2) quadrants represents total apoptosis percentage. The upper-left (Q4) quadrant is the percentage of necrosis and lower-left (QI) quadrant corresponds to viable cells. Data represent one experiment.

Abbreviations: $\mathrm{MN}$, mononuclear; PI, propidium iodide.

test different barium chloride concentrations and incubation periods are needed to produce dose-dependent curves.

\section{Conclusion}

Nanoparticles of barium chloride have immunotoxic effects on colostral MN phagocytes. Barium toxicity likely extends to other cell types, showing the importance of avoiding exposure to this chemical agent, especially for nursing mothers. Accordingly, health education programs should be developed to avoid exposure to barium and other chemical agents.

\section{Acknowledgments}

This work was supported by the Conselho Nacional de Desenvolvimento Científico e Tecnológico (CNPq), Brazil, Fundação de Apoio a Pesquisa de Mato Grosso (FAPEMAT), Brazil, and Coordenação de Aperfeiçoamento de Pessoal de Nível Superior, CAPES, Brazil.

\section{Author contributions}

All authors contributed toward data analysis, drafting and critically revising the paper, and agree to be accountable for all aspects of the work. L Mores carried out the assay, participated in the sequence alignment, and drafted the manuscript. EL França and EA Suchara participated in the design of the study, coordination, and helped to draft the manuscript. NA Silva participated in the collection of samples, carried out the assays, and helped to draft the manuscript. AC HonorioFrança carried out the assay, conceived the study, carried out the assays, participated in its design and coordination, and helped to draft the manuscript.

\section{Disclosure}

The authors declare no conflicts of interest in this work.

\section{References}

1. Field CJ. The immunological components of human milk and their effect on immune development in infants. Am Soc Nutr Sci. 2005; 135:1-4.

2. Hanson LA. Session 1: feeding and infant development breast-feeding and immune function. Proc Nutr Soc. 2007;66:384-396.

3. Chirico G, Marzollo R, Cortinovis S, Fonte C, Gasparoni A. Antiinfective properties of human milk. $J$ Nutr. 2008;138:1801S-1806S.

4. Holmlund U, Amoudruz P, Johansson MA, et al. Maternal country of origin, breast milk characteristics and potential influences on immunity in offspring. Clin Exp Immunol. 2010;162:500-509.

5. França EL, Nicomedes TR, Calderon IMP, Honorio-França AC. Timedependent alterations of soluble and cellular components in human milk. Biol Rhythm Res. 2010;41:543-547.

6. Carrichon L, Picciocchi A, Debeurme F, et al. Characterization of superoxide overproduction by the D-Loop(Nox4)-Nox2 cytochrome b(558) in phagocytes - differential sensitivity to calcium and phosphorylation events. Biochim Biophys Acta. 2011;1808:78-90.

7. Honorio-França AC, Carvalho MP, Isaac L, Trabulsi LR, CarneiroSampaio MM. Colostral mononuclear phagocytes are able to kill enteropathogenic Escherichia coli opsonized with colostral IgA. Scand J Immunol. 1997;46:59-66.

8. França-Botelho AC, Honorio-França AC, Franca EL, Gomes MA, Costa-Cruz JM. Phagocytosis of Giardia lamblia trophozoites by human colostral leukocytes. Acta Paediatr. 2006;95:438-443.

9. França EL, Bittercourt R, Fijimori M, Moraes TC, Calderon IMP, Honorio-França AC. Human colostral phagocytes eliminate enterotoxigenic Escherichia coli opsonized by colostrum supernatant. JMicrobiol Immunol Infect. 2011;44:1-7.

10. França EL, Morceli G, Fagundes DLG, Rudge MVC, Calderon IMP, Honorio-França AC. Secretory IgA-FC $\alpha$ R receptor interaction modulating phagocytosis and microbicidal activity by phagocytes in human colostrum of diabetics. APMIS. 2011;119:710-719.

11. Honorio-França AC, Hara CCP, Ormonde JVS, Nunes GT, França EL. Human colostrum melatonin exhibits a day-night variation and modulates the activity of colostral phagocytes. J Appl Biomed. 2013;11: $153-162$.

12. Nickerson K. Environmental contaminants in breast milk. J Midwifery Womens Health. 2006;51:26-34.

13. Almeida AA, Lopes CM, Silva AM, Barrado E. Trace elements in human milk: correlation with blood levels, inter-element correlations and changes in concentration during the first month of lactation. $J$ Trace Elem Med Biol. 2008;22:196-205.

14. Christensen JM. Human exposure to toxic metals: factors influencing interpretation of biomonitoring results. Sci Total Environ. 1995; 166:89-135.

15. Pronczuk J, Akre J, Moy G, Vallenas C. Global perspectives in breast milk contamination: infectious and toxic hazards. Environ Health Persp. 2002;110:A349-A351.

16. Khlifi R, Hamza-Chaffai A. Head and neck cancer due to heavy metal exposure via tobacco smoking and professional exposure: a review. Toxicol Appl Pharmacol. 2010;248:71-88. 
17. Falomir P, Alegría A, Barberá R, Farré R, Lagarda MJ. Direct determination of lead in human milk by electrothermal atomic absorption spectrometry. Food Chem. 1999;64:111-113.

18. Coni E, Bocca B, Galoppi B, Alimonti A, Caroli S. Identification of chemical species of some trace and minor elements in mature breast milk. Microchem J. 2000;67:187-194.

19. Purdey M. Chronic barium intoxication disrupts sulphated proteoglycan synthesis: a hypothesis for the origins of multiple sclerosis. Med Hypotheses. 2004;62:746-754.

20. Dórea JG, Donangelo CM. Early (in uterus and infant) exposure to mercury and lead. Clin Nutr. 2006;25:369-376.

21. Kazi TG, Jalbani N, Baig JÁ, et al. Assessment of toxic metals in raw and processed milk samples using electrothermal atomic absorption spectrophotometer. Food Chem Toxicol. 2009;47:2163-2169.

22. Örün E, Yalçin SS, Aykut O, et al. Breast milk lead and cadmium levels from suburban areas of Ankara. Sci Total Environ. 2011; 409(2467-2472):2011.

23. Bleackley MR, Macgillivray RTA. Transition metal homeostasis: from yeast to human disease. Biometals. 2011;24:785-809.

24. Thang ND, Yajima I, Kumasaka MY, et al. Barium promotes anchorageindependent growth and invasion of human $\mathrm{HaCaT}$ keratinocytes via activation of c-SRC kinase. PLoS One. 2011;6:1-8.

25. Oscarsson A, Reeves AL. Barium. In: Nordberg GF, Fowler BA, Nordberg M, Friberg LF, editors. Handbook on the Toxicology of Metals. Amsterdam: Elsevier; 2007:407-414.

26. Millour S, Noel L, Chekri R. Strontium, silver, tin, iron, tellurium, gallium, germanium, barium and vanadium levels in foodstuffs from the Second French Total Diet Study. J Food Compos Anal. 2012;25: $108-129$.

27. Syed IB, Hosain F. Determination of LD50 of barium chloride and allied agents. Toxicol Appl Pharmacol. 1972;22:150-152.

28. Roza O, Berman LB. The pathophysiology of barium: hypokalemic and cardiovascular effects. J Pharm Exp Ther. 1971;177:433-439.

29. Schroeder HA, Tipton IH, Nason AP. Trace metals in man: strontium and barium. J Chronic Dis. 1972;25:491-517.

30. Agency for Toxic Substances and Disease Registry (ATSDR). Toxicological Profile for Barium and Barium Compounds. Atlanta: U.S. Department of Health and Human Services; 2007:1-179.

31. Morceli G, Honorio-França AC, Fagundes DLG, Calderon IMP, França EL. Antioxidant effect of melatonin on the functional activity of colostral phagocytes in diabetic women. PLoS One. 2013;8:e56915.

32. Fagundes DLG, França EL, Hara CCP, Honorio-França AC. Immunomodulatory effects of poly (ethylene glycol) microspheres adsorbed with cortisol on activity of colostrum phagocytes. Int J Pharmacol. 2012;8: 510-518.

33. Pundt N, Peters MA, Wunrau C, et al. Susceptibility of rheumatoid arthritis synovial fibroblasts to FasL- and TRAIL-induced apoptosis is cell cycle-dependent. Arth Res Ther. 2009;11:1-10.
34. Diaz P, Vallejos C, Guerrero I, Riquelme G. Barium, TEA and sodium sensitive potassium channels are present in the human placental syncytiotrophoblast apical membrane. Placenta. 2008;29:883-891.

35. Wones RG, Stadler BL, Frohman LA. Lack of effect of drinking water barium on cardiovascular risk factors. Environ Health Persp. 1990; 85:355-359

36. Pessoa RS, França EL, Ribeiro EB, Abud NG, Honorio-França AC. Microemulsion of babassu oil as a natural product to improve human immune system function. Drug Des Dev Ther. 2014;9:21-31.

37. Fagundes DLG, França EL, Morceli G, Rudge MVC, Calderon IMP, Honorio-França AC. The role of cytokines in the functional activity of phagocytes in blood and colostrum of diabetic mothers. Clin Dev Immunol. 2013;2013:590190.

38. Rasmussen H, Barrett P, Smallwood J, Bollag W, Isales C. Calcium ion as intracellular messenger and cellular toxin. Environ Health Persp. 1990;84:17-25.

39. Carafoli E. Intracellular calcium homeostasis. Ann Rev Biochem. 1987; $56: 395-433$

40. Novak EJ, Rabinovitch PS. Improved sensitivity in flow cytometric intracellular ionized calcium measurement using Fluo-3/Fura Red fluorescence ratios. Cytometry. 1994;17:135-141.

41. Suriyo T, Watcharasit P, Thiantanawat A, Satayavivad J. Arsenite promotes apoptosis and dysfunction in microvascular endothelial cells via an alteration of intracellular calcium homeostasis. Toxicol In Vitro. 2012; 26:386-395.

42. Schanne FAX, Moskal JR, Gupta RK. Effect of lead on intracellular free calcium ion concentration in a presynaptic neuronal model: 19F-NMR study of NG108-15 cells. Brain Res. 1989;503:308-311.

43. Okamoto Y, Kagaya A, Motohashi N, Yamawaki S. Inhibitory effects of lithium ion on intracellular $\mathrm{Ca}^{2+}$ mobilization in the rat hippocampal slices. Neurochem Int. 1995;26:233-238.

44. Biagioli M, Pifferi S, Ragghianti M, Bucci S, Rizzuto R, Pinton P. Endoplasmic reticulum stress and alteration in calcium homeostasis are involved in cadmium-induced apoptosis. Cell Calcium. 2008; 43(184-195):2008.

45. Koudrine AV. Trace elements and apoptosis. J Trace Elem Med Biol. 1998;12:65-76.

46. Cano-Abad MF, García AG, Sánchez-García P, López MG. Ba2+ induced chromaffin cell death: cytoprotection by $\mathrm{Ca}^{2+}$ channel antagonists. Eur J Pharmacol. 2000;402:19-29.

47. Catelas I, Petit A, Vali H, et al. Quantitative analysis of macrophage apoptosis vs. necrosis induced by cobalt and chromium ions in vitro. Biomaterials. 2005;26:2441-2453.
International Journal of Nanomedicine

\section{Publish your work in this journal}

The International Journal of Nanomedicine is an international, peerreviewed journal focusing on the application of nanotechnology in diagnostics, therapeutics, and drug delivery systems throughout the biomedical field. This journal is indexed on PubMed Central, MedLine, CAS, SciSearch ${ }^{\circledR}$, Current Contents ${ }^{\circledR} /$ Clinical Medicine,

\section{Dovepress}

Journal Citation Reports/Science Edition, EMBase, Scopus and the Elsevier Bibliographic databases. The manuscript management system is completely online and includes a very quick and fair peer-review system, which is all easy to use. Visit http://www.dovepress.com/ testimonials.php to read real quotes from published authors. 